\title{
$\mathrm{E}$ 형간염의 역학, 진단 및 치료
}

\author{
허내윤 \\ 인제대학교 의과대학 인제대학교 해운대백병원 소화기내과
}

\section{Hepatitis E Virus: Epidemiology, Diagnosis, and Management}

\author{
Nae-Yun Heo
}

Division of Gastroenterology, Inje University Haeundae Paik Hospital, Inje University College of Medicine, Busan, Korea

The HEV is a known cause of water-borne outbreaks of acute non-A non-B hepatitis in developing countries, which affects young people and may result in high mortality in pregnant women. In recent decades, however, HEV genotypes 3 and 4 have been known as a cause of sporadic zoonotic infections in older males from swine HEV worldwide. Most acute HEV infections are self-limited. On the other hand, in immunosuppressed patients, including solid organ transplant recipients, chronic HEV infections may exist and progress to liver cirrhosis or decompensation. Therefore, physicians need to recognize HEV as a major pathogen for acute and chronic hepatitis of unknown causes and investigate this disease. (Korean J Gastroenterol 2019;74:130-136)

Key Words: Hepatitis E; Waterborne diseases; Zoonoses; Genotype

\section{서 론}

E형간염 바이러스(HEV)는 Hepeviridae과 Hepevirus속의 유일한 종으로 분류되는 RNA 바이러스로서 다른 간염 바이 러스에 비하여 뒤늦게 명명되었으나, 실제로 그 존재가 알려 진 것은 1980년대 초반이었다. 1979년 인도 카슈미르에서 황 달을 동반한 중증 급성 간염이 발생하였다. 당시 소화기전문 의 Khuroo는 이에 관하여 자세한 역학 조사 및 혈청 검사를 시행하였고, 식수원 오염에 의한 수인성 감염을 일으키는 non-A, non-B hepatitis가 있음을 발표하였다. 1983년 소련 의 바이러스 연구자 Balayan 등 ${ }^{2}$ 은 중앙아시아에 주둔 중인 군인들 사이에 비슷한 양상의 원인 불명 간염이 발생하자 환 자의 분변 추출물을 직접 섭취하여 자가 감염이 일어나게 하 였다. 이후 전형적인 간염 증상을 겪으면서 본인의 분변 표본 을 전자현미경으로 관찰하여 virus-like particle이 있음을 확
인하였다. 하지만 분변 검체에서 확인되는 바이러스의 양이 극히 적어 추가 연구에 어려움을 겪다 1991년에 바이러스 염 기서열이 확인되었고, 효소면역법을 통한 $\mathrm{HEV}$ 항체 검사가 개발되었다. ${ }^{3,4}$ 이후 본격적으로 $\mathrm{HEV}$ 에 관한 역학 조사가 이 루어져 $\mathrm{HEV}$ 가 위생 상태가 불량한 개발도상국에서 집단 발 병하는 급성 간염의 주요 원인임을 알게 되었고, 최근 십여 년 동안 선진국에서도 인수공통감염(zoonotic infection)으로 전염되는 간염 바이러스로 확인되었다. 또한, 면역억제자에 서는 만성화되어 간경변증으로 신속히 진행하는 것으로 알려 져 최근 임상적 중요도가 높은 질환으로 인식되고 있다.

\section{본 론}

\section{1. 역학}

$\mathrm{HEV}$ 는 여러 유전자형이 포유동물, 조류, 어류에서 확인되

Received August 12, 2019. Revised August 27, 2019. Accepted August 28, 2019.

(C) This is an open access article distributed under the terms of the Creative Commons Attribution Non-Commercial License (http://creativecommons.org/licenses/ by-nc/4.0) which permits unrestricted non-commercial use, distribution, and reproduction in any medium, provided the original work is properly cited.

Copyright (c) 2019. Korean Society of Gastroenterology.

교신저자: 허내윤, 48108, 부산시 해운대구 해운대로 875 , 인제대학교 의과대학 인제대학교 해운대백병원 소화기내과

Correspondence to: Nae-Yun Heo, Division of Gastroenterology, Inje University Haeundae Paik Hospital, Inje University College of Medicine, 875 Haeun-daero, Haeundae-gu, Busan 48108, Korea. Tel: +82-51-797-2446, Fax: +82-51-797-1340, E-mail: nyheo@hanmail.net, ORCID: https://orcid.org/0000-0001-6571-8935

Financial support: None. Conflict of interest: None. 
었고, 이 중 인체 감염을 주로 일으키는 유전자형은 1-4형으로 알려져 있다. 최근 낙타고기를 섭취한 사람에서 유전자 7형에 의한 $\mathrm{E}$ 형간염이 보고되었다.

\section{1) 유전자 1형 및 2형 E형간염}

유전자 1형(HEV-1)과 2형(HEV-2)은 인체 감염만 일으키 며 HEV-1은 인도, 동남아시아, 중앙아시아와 중동, 북아프리 카에서 토착화되어 집단 발병 사례가 보고되고 있으며, 멕시 코와 일부 아프리카 국가에서 $\mathrm{HEV}$-2가 집단 발생하였다. 이

A

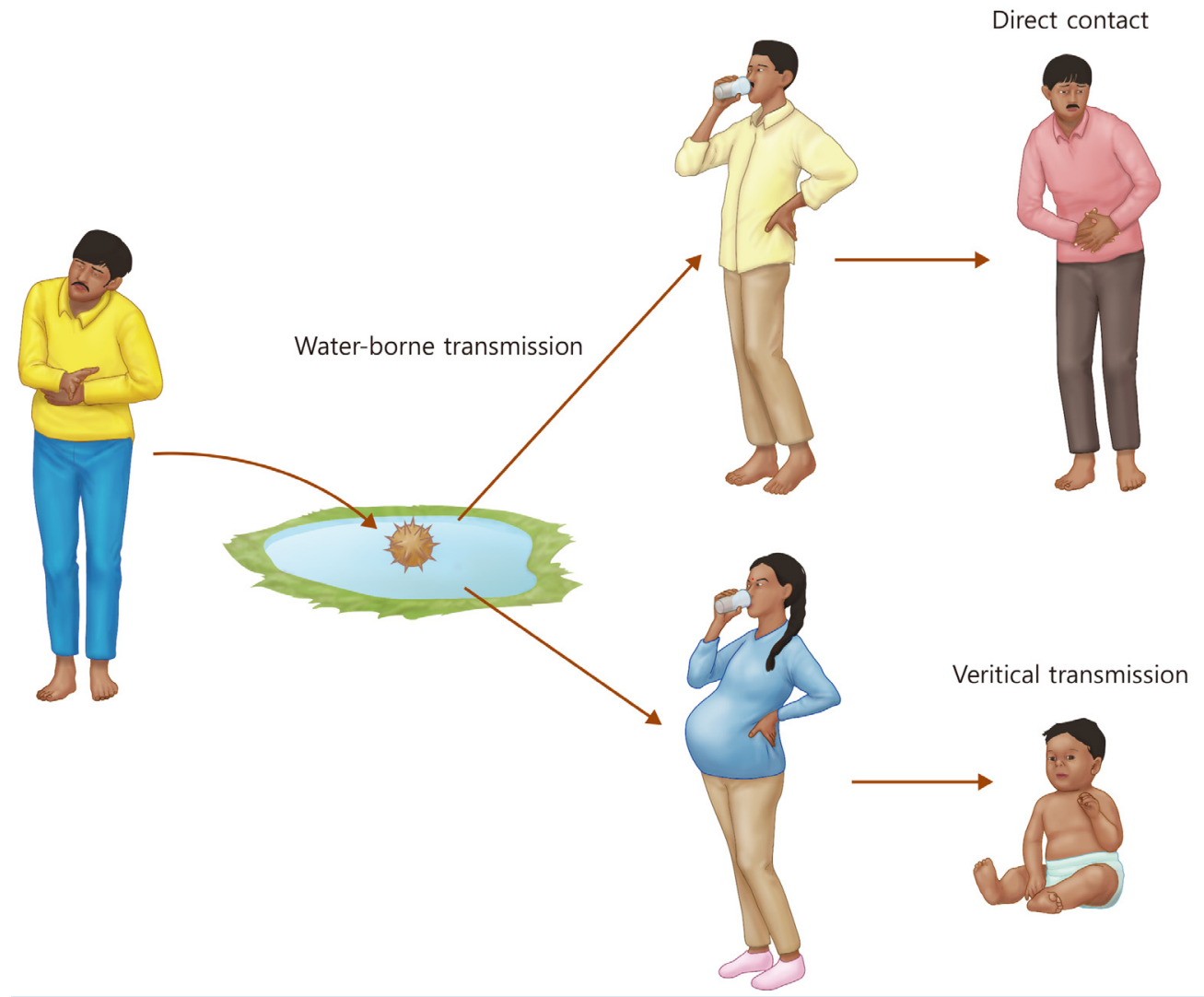

B

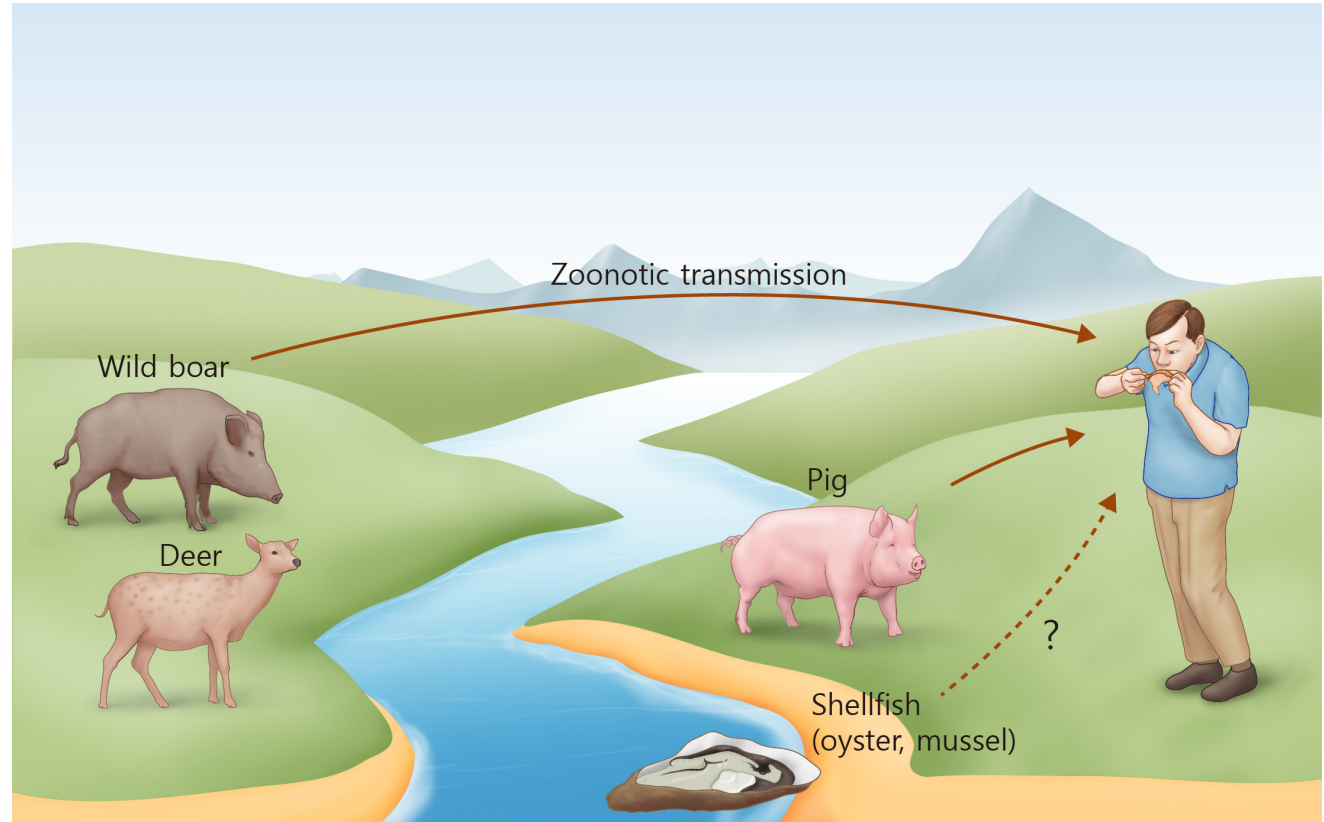

Fig. 1. Transmission route of hepatitis E virus genotype 1 and 2 (A), and genotype 3 and 4 (B). 
들 지역에서는 분변-경구 감염이 주로 발생하며, 하수도 시설 이 잘 갖추어 지지 않은 지역에서 분변에 오염된 음용수가 주된 감염원으로 여겨진다. ${ }^{1}$ 인도에서 $\mathrm{HEV}$ 유행 이후 가정 내 환자 접촉자 중 $29 \%$ 에서 감염이 발생하여 사람 대 사람 감염도 가능하다는 보고가 있으나, ${ }^{5}$ 가족 내 접촉 후 전염력이 낮다는 보고도 있어 이에 관련하여 논란이 있다. ${ }^{6,7} \mathrm{HEV}$-1과 $\mathrm{HEV}-2$ 의 경우 임산부 간염 시 간부전으로 진행하여 치사율 이 매우 높으며, 태아에게 자궁 내 감염을 일으켜 사산이나 출생 후 급성 간염에 의한 사망률을 높이는 것으로 알려졌 다(Fig. 1A). ${ }^{8}$

\section{2) 유전자 3형 및 4형 E형간염}

유전자 3형(HEV-3)과 4형(HEV-4)은 인수공통감염을 일으 키며 유럽, 북미, 아시아 일부(일본, 대만), 호주, 뉴질랜드 등 선진국에서 산발적 발생이 보고되었다. 이 지역에서 $\mathrm{HEV}$ 는 돼지, 멧돼지, 사슴 등에 감염되어 있으며, 인체 감염은 이러 한 동물의 고기를 덜 익힌 채로 섭취하거나 밀접한 접촉을 하였을 때 발생하는 것으로 추정된다(Fig. 1B). 유럽에서는 최 근 E형간염 바이러스가 급성 바이러스 간염의 주요 원인으로 알려지고 있으며, 프랑스 남부 등 일부 지역에서 발생률이 매 우 높다. 특히, 코르시카에서 유래한 figatellu는 돼지의 간으 로 만든 소시지의 일종으로 이를 섭취한 후 $\mathrm{E}$ 형간염의 집단 발병이 있었다. ${ }^{9}$ 감염된 돼지를 도축하고 가공하는 과정에서 $\mathrm{HEV}$ 가 식품에 오염될 수 있다. 영국에서 발표된 자료에 따르 면 돼지 도축장, 가공 공장, 판매점에서 채집된 돼지 분변 및 간, 소시지 검체에서 $\mathrm{HEV} \mathrm{PCR} \mathrm{양성으로} \mathrm{돼지고기} \mathrm{소시지에}$ 의한 감염 우려가 있음을 보여주었다. ${ }^{10}$ 영국 및 네덜란드에서 발표한 환자-대조군 연구에 따르면, 돼지고기 햄 및 소시지 등의 섭취가 E형간염 발생과 연관이 있었다. ${ }^{11,12}$ 2017년 발표
된 유럽질병예방센터 조사 보고에 따르면 유럽에서 $\mathrm{HEV}$ 감 염 사례가 2005년 514건에서 2015년 5,617건으로 10배 증가 하였다. ${ }^{13}$ 이러한 발생률 증가가 실제 발생이 증가한 것인지 $\mathrm{E}$ 형간염에 관한 인지도가 높아져 관련 검사의 시행 증가에 따른 것인지는 확실하지 않다. 일본에서는 멧돼지 및 사슴고 기 섭취 후 $\mathrm{HEV}$ 발생 보고들이 있었다. ${ }^{14-16}$ 중국의 경우 과거 유전자 1형이 우세하였으나 최근에는 유전자 4형이 가장 흔 한 원인으로 보고되고 있다. 이는 위생시설의 향상으로 수인 성 감염에 의한 $\mathrm{HEV}$ 1형 감염이 줄어든 반면, 가축에 토착화 되었던 $\mathrm{HEV}$ 4형이 지속 발생하기 때문으로 추정된다. ${ }^{17} \mathrm{E}$ 형 간염은 드물지만 수혈을 통해서도 감염될 수 있다. 유럽에서 는 HEV-3가, 일본에서는 HEV-3와 HEV-4가 수혈에 의하여 감염되었음이 보고되었다. 영국의 한 연구에 따르면 225,000 명 의 헌혈자 중 79 명에게서 $\mathrm{HEV}$ 바이러스혈증이 확인되었고, 이들에게서 수혈을 받은 43 명 중 18명에서 바이러스 감염이 발생하였다. ${ }^{18}$ 헌혈 공여자 선별 검사에 $\mathrm{E}$ 형간염을 포함시킬 지에 관해서는 수혈의학계에 논란이 있는 사안이나 영국, 아 일랜드, 프랑스, 네덜란드 및 일본에서는 $\mathrm{HEV}$ 에 대한 헌혈 공여자 검사가 이루어지고 있다.

\section{3) 국내 E형간염 현황}

국내에서는 2002년에서 2015년에 걸쳐 20여 건의 급성 E형 간염 증례가 보고되었다. 이 중 유행 지역을 방문한 환자는 3 명이었고, 나머지는 토착 감염으로 평가되었다. ${ }^{19-27}$ 대부분 의 증례에서 감염 경로가 확인되지 않았으나 멧돼지 담즙을 마신 후 감염된 사례와 야생 사슴 및 노루고기 섭취 후 감염된 사례가 확인되었고, ${ }^{24,25,27}$ 유전자형은 3건에서 4형으로 분석 되었다. ${ }^{24-26}$ 국내 건강검진자 361 명 중 $12 \%$ 에서 anti-HEV가 검출되었고, ${ }^{28}$ 도축 산업 종사자 1,848 명 중 $33.5 \%$ 에서 $\mathrm{IgG}$

Table 1. Epidemiological and Clinical Features of Hepatitis E Virus Infection according to Genotype

\begin{tabular}{|c|c|c|}
\hline & HEV-1 \& HEV-2 & HEV-3 \& HEV-4 \\
\hline Geographic distribution & $\begin{array}{l}\text { India, Central Asia, Middle East, North Africa (HEV-1) } \\
\text { Mexico, West Africa (HEV-2) }\end{array}$ & $\begin{array}{c}\text { Europe, North America, South America (HEV-3) } \\
\text { China (HEV-4) } \\
\text { Japan (HEV-3, HEV-4) }\end{array}$ \\
\hline Infection source & Human & Zoonotic: pig, wild boar, deer \\
\hline Transmission route & $\begin{array}{l}\text { Fecal to oral transmission via infected water } \\
\text { Person-to-person contact vertical transmission }\end{array}$ & $\begin{array}{l}\text { Consumption of infected animals } \\
\text { Transfusion via infected blood product }\end{array}$ \\
\hline Outbreak & Epidemic or endemic & Sporadic \\
\hline Intra-familial spread & Yes & No \\
\hline Age & Mainly affects young adults & Mainly affects older men \\
\hline Chronic infection & No & Yes, in immunocompromised \\
\hline Pregnancy & Mortality $25 \%$ & Increased mortality not seen \\
\hline Underlying chronic liver disease & Increased mortality & Increased mortality \\
\hline Neurologic complications & Poorly documented & Yes in HEV-3 \\
\hline
\end{tabular}

HEV-1, hepatitis E virus genotype 1; HEV-2, hepatitis E virus genotype 2; HEV-3, hepatitis E virus, genotype 3; HEV-4, hepatitis E virus genotype 4. 
anti-HEV가 양성, $0.5 \%$ 에서 IgM anti-HEV가 양성으로 검 출되어 국내에서도 $\mathrm{E}$ 형간염이 무증상 감염을 비롯하여 다양 한 임상 양상으로 발현할 것으로 추정된다. ${ }^{29}$ 한편, 국내 14 곳 돼지 농장에서 148 건의 분변 검체를 분석한 결과 $20.3 \%$ 에서 $\mathrm{HEV}$ RNA가 양성으로 나왔고, $\mathrm{HEV}-3 \mathrm{a}$ 와 $\mathrm{HEV}-4 \mathrm{c}$ 가 검출되 어 $^{30}$ 국내에서 유전자 3형에 의한 감염 가능성이 있으나 아직 보고된 바는 없다. 국내 해안에서 채취한 굴 161건을 분석한 결과 14건에서 $\mathrm{HEV} \mathrm{RNA}$ 가 검출되어 $\mathrm{HEV}$ 에 오염된 조개류 섭취에 의한 E형간염 발생 가능성이 있다(Fig. 1). ${ }^{31}$

\section{2. 임상 양상}

$\mathrm{HEV}$ 는 전형적인 급성 간염 양상으로 나타나지만 임상의 사가 E형간염을 의심하여 검사를 시행하지 않으면 원인 불명 의 간염 혹은 약제 유발 간 손상으로 잘못 진단될 수 있다. 특히 신경학적 이상을 동반하는 간염이 발생할 경우 $\mathrm{E}$ 형간염 여부에 대한 확인이 요망된다(Table 1).

\section{1) 급성 $E$ 형간염}

개발도상국에서는 HEV-1 및 HEV-2에 의하여 주로 젊은 성인에게서 발병한다. 산발적으로 발생하기도 하나 수백에서 수천 명이 집단 발병하기도 하였다. 잠복기는 약 40 일이며, 무증상인 경우부터 전격성 간염까지 다양한 임상 양상을 보이 며, 사망률은 약 $1 \%$ 로 보고되었다. 전형적인 증상은 피로감, 식욕부진, 오심, 구토, 발열, 복통, 황달 등이며, 아미노전달효 소 및 빌리루빈이 상승하였다가 대개 6주 이내 정상화된다. 선진국에서 산발적으로 발생하는 $\mathrm{E}$ 형간염도 유사한 급성 간 염 양상을 보이나 일부에서 신경학적 합병증을 동반한다. 대 개 무증상이나 임상증상은 중년이나 노년층의 남성 환자에게 서 관찰된다. ${ }^{32,33}$

\section{2) 만성 $E$ 형간염}

HEV-3 및 HEV-4 감염은 면역억제자에서 만성 간염으로 진행할 수 있다. 만성 $\mathrm{E}$ 형간염은 고형 장기 이식 환자, $\mathrm{CD} 4+$ T세포가 적은 HIV 감염자, 항암 치료를 받는 혈액암 환자 등 에게서 보고되었다. 관찰 연구에 따르면, $\mathrm{HEV}$ 에 감염된 고형 장기 이식 환자에게서 바이러스의 자연 소실은 3 개월 이내 일어나는 것으로 확인되어, 감염 후 3 개월 이상 바이러스혈증 이 지속되는 경우를 만성 $\mathrm{E}$ 형간염으로 간주하고 치료하는 것 이 타당하다. 프랑스 보고에 따르면, 고형 장기 이식 환자의 0.9-3.5\%에서 HEV RNA가 검출되었으며, ${ }^{34,35} 60 \%$ 에서 급성 간염이 만성 간염으로 진행하였다. ${ }^{36}$ 만성 간염이 발생할 경우 급속한 간섬유화가 일어날 수 있고, 몇몇 환자는 간경변증, 비대상성 간부전, 사망에 이르기도 한다. ${ }^{32,33}$

\section{3) 신경학적 합병증}

여러 간 외 합병증이 발생할 수 있으나 신경학적 합병증이 가장 중요하다. 보고에 따르면 $\mathrm{E}$ 형간염 환자의 $8 \%$ 에서 신경 학적 합병증이 발생하였다. ${ }^{37}$ 가장 흔한 질환은 길랑-바레 증 후군, 신경통성 근위축(neuralgic amyotrophy), 뇌막염/뇌염 등이다. 한 보고에 따르면, $\mathrm{HEV}$-연관 신경통성 근위축은 양 측성으로 발병하고, 상완신경총을 잘 침범하며, 횡격막 신경 을 침범하는 것이 특징적인 것으로 나타났다. ${ }^{38}$ 국내에서도 길 랑-바레 증후군을 동반한 사례가 보고된 바 있다. ${ }^{27}$

\section{3. 진단}

급성 $\mathrm{E}$ 형간염 시기에 검사실 소견은 전형적인 급성 바이러 스 감염의 양상을 보인다. 2-6주간 잠복기 후 혈액 및 분변에 서 바이러스가 검출되며, 이 시기에 ALT가 상승하고, 특이 항체가 나타날 즈음에 최고치에 도달한다. 항 $\mathrm{HEV}$ 항체 중 $\mathrm{IgM}$ 이 먼저 나타나고, $\operatorname{IgG}$ 가 뒤이어 나타난 뒤 수년간 지속 된다. 혈청 및 분변 RNA는 임상증상이 발현되기 직전에 검출 되어 ALT가 최고치에 도달한 후 1-2주까지 측정된다. 급성 $\mathrm{E}$ 형간염이 발생할 경우 $\mathrm{HEV}$ 특이 IgM이 양성이나 검사 방 법에 따라 민감도와 특이도에 차이가 있다. $\mathrm{IgG}$ 혈청 검사에 근거한 지역별 $\mathrm{E}$ 형간염의 유병률을 비교할 때에는 같은 종류 의 검사 결과를 비교해야 한다. 프랑스 혈액 공여자를 대상으 로 한 조사에 따르면 혈청 검사 방법에 따라 항 $\mathrm{HEV} \mathrm{IgG의}$ 양성률이 $16.6 \%$ vs. $52.5 \%$ 로 큰 차이를 보였다. ${ }^{39,40}$ 또한, 어 떤 HEV 혈청 검사는 Epstein-Barr 바이러스와 거대세포바이 러스와 높은 교차 반응을 보여, HEV IgM 양성 환자의 33.3\% 및 24.2\%에서 Ebstein-Barr 바이러스, 거대세포바이러스와 교차 반응을 나타내기도 하였다. ${ }^{41}$ 국내에서는 급성 $\mathrm{A}$ 형간염 에서 HAV IgM와 HEV IgM이 공동 양성으로 나온 경우가 있었으나, ${ }^{42,43}$ 두 가지 바이러스의 공통 감염인지 $\mathrm{HEV} \mathrm{IgM}$ 의 위양성인지 확인되지 않았다. 따라서, 혈청 검사에서 $\mathrm{HEV}$ 감염이 의심될 경우 확진을 위하여 $\mathrm{HEV}$ RNA 검사를 시행하 는 것이 바람직하다.

한편, 면역억제자인 경우 $\mathrm{HEV}$ 특이 항체가 흔히 검출되지 않으므로 HEV RNA 측정이 유일하게 신뢰할 수 있는 검사법 이다. 만성 간염은 적어도 3 개월 동안 $\mathrm{HEV}$ RNA가 검출되었 을 때로 정의한다. HEV RNA를 측정하는 핵산증폭기법에는 reverse transcriptase PCR, nested PCR, real-time PCR 등 여러 방법이 있으나 검사법마다 측정치의 변이가 크다. 이에 $\mathrm{HEV}$ RNA 측정에 관하여 세계보건기구(World Health Organization) International Standard를 제정하여 공통 단 위인 IU로 표시하여 여러 검사실에서 보고하는 결과의 비교가 가능하게 되었다. ${ }^{44}$ 상용화된 real-time PCR 검사로서 RealStar HEV RT-PCR 1.0 kit (Altona Diagnostics, Hamburg, 
Germany), AmpliCube HEV 2.0 kit (Mikrogen Diagnostik, Lubbock, TX, USA), hepatitis@ceeramTools kit (Ceeram, La Chapelle-sur-Erdre, France) 등이 있으며, 이 중 RealStar HEV RT-PCR 1.0 kit가 가장 높은 민감도를 보였다. ${ }^{45}$ 국내에 는 아직 상용화된 real-time $\mathrm{HEV} \mathrm{PCR} \mathrm{검사법이} \mathrm{도입되지}$ 않았으며, 주요 수탁 검사기관에서는 in-house method로 reverse transcriptase PCR 검사를 통한 정성 검사만 시행하고 있다.

\section{4. 치료}

현재 페그-인터페론-a와 리바비린를 이용한 항바이러스 치 료가 알려져 있다.

\section{1) 급성 $E$ 형간염}

급성 $\mathrm{E}$ 형간염은 대개 보존적인 치료로 호전되나 기저 만성 간질환이 있는 환자의 경우 전격성 간부전으로 진행할 위험이 있다. 따라서, 중증 급성 간염이나 만성 간질환의 급성 간부전 (acute-on-chronic liver failure) 시 리바비린 치료를 고려할 수 있다. ${ }^{33}$

\section{2) 고형 장기 이식 환자의 만성 $\mathrm{E}$ 형간염}

만성 $\mathrm{E}$ 형간염 환자의 $1 / 3$ 에서 tacrolimus와 스테로이드 등 T세포에 작용하는 면역억제제를 감량하였을 때 $\mathrm{HEV}$ 바이러 스의 자연 소실이 보고된 바 있다. 또한, 리바비린 3개월 요법 으로 $78 \%$ 의 환자들이 지속바이러스 반응을 보였고, 재발한 환자를 6 개월까지 연장 치료하였을 때 지속바이러스 반응을 달성할 수 있었다. ${ }^{46}$ 간 이식 환자에게서 페그-인터페론-a가 소수의 환자들을 성공적으로 치료한 보고가 있으나, 인터페론 은 거부 반응 발생 위험이 있으므로 리바비린 치료에 반응이 없는 경우 제한적으로 사용해야 한다. ${ }^{33}$ Sofosbuvir와 리바바 린 병합 요법이 급/만성 $\mathrm{E}$ 형간염에서 항바이러스 효과를 보 였다는 보고들이 있으나 효과적인 치료 기간에 관하여 정립된 바 없다. ${ }^{47,48}$ 현재 유럽에서 리바비린 3개월 치료에 실패한 만 성 E형간염을 환자를 대상으로 sofosbuvir 24주 요법에 관한 임상시험이 진행 중이다. ${ }^{49}$

\section{3) 기타 면역억제 환자의 만성 $E$ 형간염}

혈액 질환이나 HIV 환자 등 비이식 면역억제자에서 만성 $\mathrm{E}$ 형간염에 관하여 페그-인터페론-a와 리바비린 단독 혹은 복 합 요법이 효과적이었다고 보고한 소수의 증례가 있다. ${ }^{33}$

\section{5. 예방}

수인성 전염의 위험이 높은 개발도상국에서는 깨끗한 음용 수를 공급할 수 있는 국가기반시설을 유지하는 하는 것이 가
장 중요하다. ${ }^{32}$ 중국에서 개발된 백신이 유전자 1형과 4형 예 방에 모두 효과가 있는 것으로 보고되었으나 다른 국가에서는 승인을 받지 못한 상태이다. ${ }^{50}$ 국지적으로 발생하는 인수공통 감염을 예방하기 위해서는 가축, 특히 돼지고기를 포함한 음 식을 충분히 익혀서 먹어야 하며, 도축업 종사자 등 감염원에 노출이 빈번한 경우 접촉 주의가 요망된다. $\mathrm{HEV}$ 발생률이 높은 지역에서 수입된 돼지고기 가공품의 경우 시판 전 $\mathrm{HEV}$ 오염에 관하여 모니터링을 할 필요가 있다. 연안에서 채집된 굴에서 발견된 $\mathrm{HEV}$ 는 가축 분뇨에 의한 오염 가능성이 높다. 2012년부터 국내 가축 분뇨 해양 투기가 전면 금지되어 오염 가능성이 줄었으나 수산물 생산 해역 주변 하수 처리시설을 확대하여 육상 오염원 유입을 차단할 필요가 있다. 수혈에 의 한 전염을 막기 위하여 혈액 공여자 검사에 $\mathrm{HEV}$ 선별 검사를 포함시킬 수 있으며, 발생률이 높은 일부 국가에서는 이를 적 용하고 있다. ${ }^{33}$ 국내에서 $\mathrm{E}$ 형간염은 법정 전염병으로 지정되 지 않아 감염 현황에 관한 자료가 부족하다. 정부 차원에서 체계적인 역학 조사와 함께 감염 관리 대책이 세워져야 할 것이다.

\section{결 론}

$\mathrm{E}$ 형간염은 간염 바이러스 중 가장 최근에 발견되었으나 무 증상 감염이 많아 실제 유병률과 발생률이 과소평가된 경향이 있다. 특히, 국내에서는 아직 $\mathrm{E}$ 형간염의 역학에 관하여 자세 히 알려지지 않았으나 최근 인수공통감염 예들이 종종 보고되 고 있다. 따라서, 원인 불명의 간기능 이상 소견을 보이는 환 자가 E형간염 유행 지역의 여행력이 있거나 인수공통감염의 위험성이 있을 경우 $\mathrm{E}$ 형간염에 관한 적극적인 확인이 필요하 다. 또한, 정확한 진단 및 치료 반응 평가를 위하여 상용화된 $\mathrm{HEV}$ 핵산증폭검사법들이 도입되어야 할 것으로 보인다. 고 형 장기 이식이나 면역억제자에게서 원인 불명의 간염이 있을 경우 만성 $\mathrm{E}$ 형간염에 의한 간부전 위험이 있음을 의료인들이 인식하고 적극적인 대처가 요망된다. 또한, 향후 정부 차원에 서는 여러 감염원에 관한 관리를 통하여 집단 발병이 일어나 지 않도록 지속적인 노력이 필요하다.

\section{REFERENCES}

1. Khuroo MS. Discovery of hepatitis $E$ : the epidemic non-A, non-B hepatitis 30 years down the memory lane. Virus Res 2011;161: 3-14.

2. Balayan MS, Andjaparidze AG, Savinskaya SS, et al. Evidence for a virus in non-A, non-B hepatitis transmitted via the fecal-oral route. Intervirology 1983;20:23-31.

3. Tam AW, Smith MM, Guerra ME, et al. Hepatitis E virus (HEV): molecular cloning and sequencing of the full-length viral genome. 
Virology 1991;185:120-131.

4. Yarbough PO, Tam AW, Fry KE, et al. Hepatitis E virus: identification of type-common epitopes. J Virol 1991;65:5790-5797.

5. Khuroo MS, Dar MY. Hepatitis E: evidence for person-to-person transmission and inability of low dose immune serum globulin from an Indian source to prevent it. Indian J Gastroenterol 1992;11:113-116.

6. Arankalle VA, Chadha MS, Mehendale SM, Tungatkar SP. Epidemic hepatitis $\mathrm{E}$ : serological evidence for lack of intrafamilial spread. Indian J Gastroenterol 2000;19:24-28.

7. Somani SK, Aggarwal R, Naik SR, Srivastava S, Naik S. A serological study of intrafamilial spread from patients with sporadic hepatitis E virus infection. J Viral Hepat 2003;10:446-449.

8. Khuroo MS, Kamili S, Khuroo MS. Clinical course and duration of viremia in vertically transmitted hepatitis $E$ virus (HEV) infection in babies born to HEV-infected mothers. J Viral Hepat 2009;16:519-523.

9. Colson P, Borentain P, Queyriaux B, et al. Pig liver sausage as a source of hepatitis $E$ virus transmission to humans. J Infect Dis 2010;202:825-834.

10. Berto A, Martelli F, Grierson S, Banks M. Hepatitis E virus in pork food chain, United Kingdom, 2009-2010. Emerg Infect Dis 2012;18:1358-1360.

11. Said B, ljaz S, Chand MA, Kafatos G, Tedder R, Morgan D. Hepatitis $E$ virus in England and Wales: indigenous infection is associated with the consumption of processed pork products. Epidemiol Infect 2014;142:1467-1475.

12. Tulen AD, Vennema H, van Pelt W, Franz E, Hofhuis A. A case-control study into risk factors for acute hepatitis $E$ in the Netherlands, 2015-2017. J Infect 2019;78:373-381.

13. European Centre for Disease Prevention and Control. Hepatitis $E$ in the EU/EEA, 2005-2015. Stockholm: European Centre for Disease Prevention and Control, 2017.

14. Masuda J, Yano K, Tamada Y, et al. Acute hepatitis E of a man who consumed wild boar meat prior to the onset of illness in Nagasaki, Japan. Hepatol Res 2005;31:178-183.

15. Mizuo H, Yazaki Y, Sugawara K, et al. Possible risk factors for the transmission of hepatitis $E$ virus and for the severe form of hepatitis E acquired locally in Hokkaido, Japan. J Med Virol 2005;76: 341-349.

16. Tei S, Kitajima N, Takahashi K, Mishiro S. Zoonotic transmission of hepatitis $E$ virus from deer to human beings. Lancet 2003; 362:371-373.

17. Dalton HR, Bendall R, ljaz S, Banks M. Hepatitis E: an emerging infection in developed countries. Lancet Infect Dis 2008;8: 698-709.

18. Hewitt PE, ljaz S, Brailsford SR, et al. Hepatitis E virus in blood components: a prevalence and transmission study in southeast England. Lancet 2014;384:1766-1773.

19. Kim NJ, Lee JS, Kim KA, et al. A case of acute hepatitis E. Taehan Kan Hakhoe Chi 2002;8:312-316.

20. Kim SS, Yeo CD, Kim JD, et al. A case of acute hepatitis $E$ with the travel history to an endemic area. Korean J Gastroenterol 2004; 44:342-345.

21. Kong SJ, Min SK, Kim IK, et al. Two cases of acute hepatitis E in patients with hyperthyroidism. Korean J Gastroenterol 2006;
47:65-71.

22. Lim JW, Park CS, Ahn JM, et al. Nine cases of sporadic acute hepatitis E in Korea. Korean J Hepatol 2006;12:230-236.

23. Lee JK, Kim YJ, Kim IK, et al. An influx case of acute hepatitis $E$ from the endemic area. Korean J Med 2008;74:S74-S77.

24. Kim YM, Jeong SH, Kim JY, et al. The first case of genotype 4 hepatitis E related to wild boar in South Korea. J Clin Virol 2011;50: 253-256.

25. Choi JY, Lee JM, Jo YW, et al. Genotype-4 hepatitis E in a human after ingesting roe deer meat in South Korea. Clin Mol Hepatol 2013;19:309-314.

26. Yun H, Kim JS, Lee HJ, et al. The complete genome sequence and molecular analysis of human hepatitis E virus genotype IV identified from a Korean patient. Arch Virol 2010;155:1003-1008.

27. Ji SB, Lee SS, Jung HC, et al. A Korean patient with Guillain-Barré syndrome following acute hepatitis $\mathrm{E}$ whose cholestasis resolved with steroid therapy. Clin Mol Hepatol 2016;22:396-399.

28. Ahn JM, Kang SG, Lee DY, Shin SJ, Yoo HS. Identification of novel human hepatitis $\mathrm{E}$ virus (HEV) isolates and determination of the seroprevalence of HEV in Korea. J Clin Microbiol 2005;43: 3042-3048.

29. Kim BS, Lim HS, Lee K, Min YS, Yoon YS, Jeong HS. A survey on the status of hepatitis e virus infection among slaughterhouse workers in South Korea. J Prev Med Public Health 2015;48: 53-61.

30. Kim YH, Park BJ, Ahn HS, et al. Detection of hepatitis E virus genotypes 3 and 4 in pig farms in Korea. J Vet Sci 2018;19:309-312.

31. Song YJ, Jeong HJ, Kim YJ, et al. Analysis of complete genome sequences of swine hepatitis $E$ virus and possible risk factors for transmission of HEV to humans in Korea. J Med Virol 2010;82: 583-591.

32. Dalton HR, Izopet J, Bendall R. Hepatitis E. In: Sanyal AJ, Boyer TD, Lindor KD, Terrault NA, eds. Zakim and Boyer's hepatology. 7th ed. Philadelphia (PA): Elsevier, 2018:522-534.

33. European Association for the Study of the Liver. EASL clinical practice guidelines on hepatitis $E$ virus infection. J Hepatol 2018;68:1256-1271.

34. Legrand-Abravanel F, Kamar N, Sandres-Saune $\mathrm{K}$, et al. Characteristics of autochthonous hepatitis $E$ virus infection in solid-organ transplant recipients in France. J Infect Dis 2010; 202:835-844

35. Abravanel F, Lhomme S, Chapuy-Regaud S, et al. Hepatitis E virus reinfections in solid-organ-transplant recipients can evolve into chronic infections. J Infect Dis 2014;209:1900-1906.

36. Kamar N, Garrouste C, Haagsma EB, et al. Factors associated with chronic hepatitis in patients with hepatitis $E$ virus infection who have received solid organ transplants. Gastroenterology 2011;140:1481-1489.

37. Woolson KL, Forbes A, Vine L, et al. Extra-hepatic manifestations of autochthonous hepatitis E infection. Aliment Pharmacol Ther 2014;40:1282-1291.

38. van Eijk JJ, Dalton HR, Ripellino P, et al. Clinical phenotype and outcome of hepatitis E virus-associated neuralgic amyotrophy. Neurology 2017;89:909-917.

39. Mansuy JM, Legrand-Abravanel F, Calot JP, et al. High prevalence of anti-hepatitis $E$ virus antibodies in blood donors from South 
West France. J Med Virol 2008;80:289-293.

40. Mansuy JM, Bendall R, Legrand-Abravanel F, et al. Hepatitis E virus antibodies in blood donors, France. Emerg Infect Dis 2011; 17:2309-2312.

41. Hyams C, Mabayoje DA, Copping R, et al. Serological cross reactivity to CMV and EBV causes problems in the diagnosis of acute hepatitis E virus infection. J Med Virol 2014;86:478-483.

42. Kang HM, Jeong SH, Kim JW, et al. Recent etiology and clinical features of acute viral hepatitis in a single center of Korea. Korean J Hepatol 2007;13:495-502.

43. Lee EJ, Kwon SY, Seo TH, et al. Clinical features of acute hepatitis A in recent two years. Korean J Gastroenterol 2008;52:298-303.

44. Baylis SA, Blümel J, Mizusawa S, et al. World Health Organization International Standard to harmonize assays for detection of hepatitis E virus RNA. Emerg Infect Dis 2013;19:729-735.

45. Al-Sadeq DW, Majdalawieh AF, Mesleh AG, Abdalla OM, Nasrallah GK. Laboratory challenges in the diagnosis of hepatitis $E$ virus.
J Med Microbiol 2018;67:466-480.

46. Kamar N, Mallet V, Izopet J. Ribavirin for chronic hepatitis E virus infection. N Engl J Med 2014;370:2447-2448.

47. Biliotti E, Franchi C, Spaziante M, et al. Autochthonous acute hepatitis $\mathrm{E}$ : treatment with sofosbuvir and ribavirin. Infection 2018;46:725-727.

48. van der Valk M, Zaaijer HL, Kater AP, Schinkel J. Sofosbuvir shows antiviral activity in a patient with chronic hepatitis $\mathrm{E}$ virus infection. J Hepatol 2017;66:242-243.

49. Hepnet pilot trial: multicenter trial for the treatment of chronic hepatitis E with sofosbuvir (SofE). [Internet]. Bethesda (MD): U.S. National Library of Medicine; 2017 Sep 14 [updated 2019 Mar 8; cited 2019 Aug 18]. Available from: https://clinicaltrials.gov/ ct2/show/NCT03282474

50. Zhang J, Shih JW, Xia NS. Long-term efficacy of a hepatitis $E$ vaccine. N EngI J Med 2015;372:2265-2266. 